\title{
THE ANALYSIS OF COVID-19 PREVENTION PRACTICES ON HEALTH CARE WORKERS IN THREE HOSPITALS IN PALEMBANG
}

\author{
Tamarakha Yumna, Nur Alam Fajar,* Rico Januar Sitorus \\ Faculty of Public Health, Universitas Sriwijaya, Jl. Palembang-Prabumulih KM 32 Ogan Ilir, 30662 , \\ Indonesia
}

\begin{abstract}
The COVID-19 pandemic is a global concern. In this case, Health Care Workers (HCW) are at the front lines in dealing with the pandemic as they provide diagnosis, care, and treatment. However, their duties have directly placed them at the most at risk of infection. Mitigation and risk reduction are crucial for safeguarding HCW' health as it prevents the spread of COVID-19. This research aimed to find out the practice of COVID-19 prevention and the correlation among practice and knowledge, attitudes, and personality traits of HCW in Palembang. A cross-sectional study was conducted between May and July 2021 on $255 \mathrm{HCW}$ who have direct contact with patients. The number of respondents per hospital is taken proportionally according to the portion of $\mathrm{HCW}$ in each selected hospital. The instrument consisted of demographic variables, knowledge, attitudes, and practices. It proves that it is reliable with Cronbach's alpha value of 0.7. The researchers used descriptive statistics, chi-square, and logistic regression. Overall, 65.2\% of participants had good knowledge, $60 \%$ had a positive attitude, and $53.3 \%$ had good practice. Education (p-value 0.022) and attitude (p-value 0.000) of HCW were all influencing factor in practice. HCW who have a negative attitude are 5.413 times more to have bad practices than those who have a positive attitude ( $p$-value $<0.001 ; P R=5.413$ ). However, training for $H C W$ and further research are recommended to analyze the availability of personal protective equipment, adequate facilities, hospital policies, or other factors that can influence and motivate the practice of $\mathrm{HCW}$.
\end{abstract}

Keywords: COVID-19, health care workers, practice

\begin{abstract}
ABSTRAK
Pandemi COVID-19 merupakan ancaman global, tenaga kesehatan berada pada garis terdepan dalam melakukan diagnosis, perawatan, dan pengobatan, sehingga tenaga kesehatan berada pada risiko terinfeksi tertinggi. Mitigasi dan pengurangan risiko sangat penting untuk melindungi kesejahteraan tenaga kesehatan dan mengurangi penyebaran COVID-19. Penelitian ini bertujuan untuk menganalisis praktik terhadap pencegahan COVID-19 dan hubungan antara praktik dengan pengetahuan, sikap serta karakteristik tenaga kesehatan di Palembang. Penelitian cross-sectional dilakukan antara Mei dan Juli 2021, di antara 255 tenaga kesehatan yang melakukan kontak langsung dengan pasien. Jumlah responden per rumah sakit diambil secara proporsional sesuai porsi tenaga kesehatan pada masing-masing rumah sakit terpilih. Instrumen yang terdiri dari karakteristik demografi, pengetahuan, sikap, dan praktik, terbukti reliabel dengan nilai cronbach's alpha 0,7. Analisis deskriptif, chi-square, dan regresi logistik dilakukan. Secara keseluruhan, 65,2\% memiliki pengetahuan yang baik, 60\% memiliki sikap positif, dan $53.3 \%$ memiliki praktik yang baik. Pendidikan (nilai-P 0,022) dan sikap tenaga kesehatan (nilai P 0,000) memengaruhi faktor perilaku. Tenaga Kesehatan yang memiliki sikap negatif beresiko 5,413 kali lebih besar untuk memiliki praktik yang buruk dibandingkan dengan sikap positif (nilai $\mathrm{P}<0,001$; PR 5,413. Namun, pelatihan bagi petugas kesehatan dan penelitian lebih lanjut disarankan untuk menganalisis ketersediaan alat pelindung diri, fasilitas yang memadai, kebijakan rumah sakit, atau faktor lain yang dapat mempengaruhi dan memotivasi praktik petugas kesehatan.
\end{abstract}

Kata Kunci: COVID-19, tenaga kesehatan, perilaku 


\section{Introduction}

COVID-19 is an acute infectious disease caused by the severe acute respiratory syndrome Coronavirus 2 (SARSCoV2). This virus infects the respiratory tract, causing respiratory failure or even human death. ${ }^{1-3}$ Starting from February 10th, 2021, more than 106 million cases and 2,325,000 deaths have been reported worldwide. The number is increasing day by day. There are more than 1.17 million confirmed cases and 31,976 deaths in Indonesia. South Sumatra Province (marked as a red zone) is the province with the seventh-highest number of confirmed cases in Indonesia, with 14,857 cases and 719 deaths. $^{4}$

In order to understand about how, when, and in what types of settings SARS-CoV-2 transmission is essential to developing the effectivity public health and infection prevention and control measures to stop the spread of this virus. The spread of SARSCoV2 occurs through contact and droplets (through infected secretions such as saliva and respiratory secretions or droplets from an infected person that come out due to coughing, sneezing, talking, or singing), air transmission (infectious substances such as $\mathrm{z}$ over long distances and time in the Air floating) and the spread of pollutants (through contaminated surfaces). ${ }^{5-7}$

OSHA (Occupational Safety and Health Administration) divided work tasks into four risk exposure levels were HCW representing the highest exposure risk. ${ }^{8}$ The number of infections and deaths of health workers has not been announced and remains unclear. Meanwhile, Bandyopadhyay's systematic review showed that infected health workers reached 14,058 (9.2\%) cases. In addition, 343 of the 1,413 cases (24.3\%) were cases of health workers who died caused by COVID-19. 9 A survey of 37 countries showing data between July 22nd and August $15^{\text {th }}, 2020$, reported that the virus has infected 299,155 health workers with 2,736 deaths. ${ }^{10}$ The Indonesian Doctors Mitigation Team revealed that the ongoing tragedy could continue and increasing the death rate. It was around 101 doctors have died due to COVID-19 reported on August 31st, 2020. ${ }^{11}$ Thus, the total of health workers who died because of COVID-19 reached 228 people. ${ }^{12}$

Mitigation and risk reduction are critical to protect the welfare of health workers and prevent the spread of COVID-19. It can be shows by strengthening the COVID-19 prevention, health, and safety protocols to maintain the safety of health workers further. WHO recommends preventing spread through the use of personal protective equipment (PPE), hand hygiene measures, implementation guidelines in health care facilities, and infection prevention and control education and training. ${ }^{13}$

Health workers are at the forefront of dealing with the COVID-19 pandemic. At this point, it puts them at the highest risk of exposure to pathogens, long working hours, psychological stress, fatigue, professional burnout and stigma, and physical violence. The lack of understanding of the 
disease among the HCWs can lead to an identification and treatment delay leading to the rapid spread of infections. The guidelines for health care professionals and online update courses have been developed by OMS, CDC, The Ministry of Health RI, and several government organizations in different countries to promote knowledge and prevention strategies. ${ }^{14}$

The study by Yupartini L et al. in Serang stated that most health care workers experience stress during work. Daily stress, compared to traumatic events, is a predictor factor that can have a more significant impact on mental health. The physiological stress response prolonged duration is a risk factor that can cause the disease. ${ }^{15}$ In addition, the study in Yogyakarta revealed that some of the respondents did not consume additional food and multivitamins to increase endurance. Not only about consuming food, but also there are still quite a few who have not complied with the use of PPE, hand-washing, or aseptic procedures before/after the process or examining patients both when dealing with COVID-19 patients, non-COVID-19 and when performing aerosol-generating actions. $^{16}$

It is necessary to pay attention to knowledge and attitudes about COVID-19. ${ }^{17}$ Study by Shariff FO et al. in Banyuasin showed a reasonably good level of knowledge and practice. It also offers a good level of attitude towards doctors about the COVID-19 pandemic. Their study suggested that the years of experience is another factor that influences practice besides knowledge and attitude. ${ }^{18}$ Furthermore, studies conducted by Giao et al. found a sufficient knowledge and a positive attitude toward COVID-19 in health workers. ${ }^{19}$ On the other hand, Bhagavathula, in her study, revealed that most of the health care workers had a lack of knowledge about COVID-19 globally. ${ }^{20}$ Sufficient knowledge will support an optimistic attitude and proper practice during work so that the risk of infection will be reduced. ${ }^{17}$ It is important to know the correlation between knowledge, attitudes, and characteristics of health workers with type of work, age, gender, education, work experience, and training, as well as their impacts on health worker compliance with COVID-19 prevention practices. The purpose of this study was to analyze the prevention practices of COVID-19 by health workers in Palembang.

\section{Method}

The cross-sectional study was conducted in the fourth week of May 2021 to July 2021. The sampling technique that used in this study is purposive sampling based on hospital ownership. The selected public hospitals are Siti Fatimah Hospital of South Sumatra (Provincial Hospital), Gandus Palembang Hospital (Regency Hospital), and selected private hospital is Sriwijaya Hospital Palembang.

Health care workers who directly contacted with patients (doctors, dentists, midwives, nurses, and analysts), and also worked in the mentioned hospitals were taken as the study population. The number of respondents per hospital was taken proportionally according to the 
portion of health care workers in each hospital until the minimum number of samples was sufficient. Respondents were adjusted by inclusion and exclusion criteria. A total of 255 healthworkers agreed to fill out the questionnaire used in this study.

In this study, the IDI guidelines from the WHO, the Decree of the Minister of Health of the Republic of Indonesia, and the Mitigation Doctors Team, have been reviewed as well as the literature on COVID-19. On the other hand, we also revised the previous studies that tested effectiveness. We have developed a questionnaire consisting of four parts: (I) demographics, (II) knowledge and (III) attitudes about COVID-19, and (IV) practices of health workers. The validation was using a pilot study on a small sample of 30 health care workers who were not included in this study. Accordingly, the revised questionnaire proved reliable, with a Cronbach's alpha value of 0.7 .

We created 12 questions about ethicology, the period of incubation, transmission, symptoms, prevention, and diagnosis of COVID-19 to facilitate an exhaustive assessment of the health-workers' knowledge. HCW attitudes were assessed with reference to 11 articles. Individually, one by one of them were asked about their felt as $\mathrm{HCW}$, meanwhile the answers are divided into categories based on the Likert scale: (1) strongly agree, (2) agree, (3) disagree, and (4) strongly disagree with the favourable and unfavourable question. Our study has evaluated HCW practices through 11 questions with four options: (1) never, (2) occasional, (3) always with a favourable and unfavourable question.

This study evaluated the KAP of health care workers based on a set of specific questions. The knowledge was classified in good and poor level. Knowledge, attitude, and practice were divided by the median. If the total is equal or higher than the median, then it will be classified as a positive attitude and vice versa. Practice can be good or bad, as well as attitudes that also can be good or bad. In this research, univariate, bivariate, and multivariate analysis data were used. The univariate analysis aimed to describe each variable. Bivariate analysis, in this case, used chi-square and analysis of variance, $\mathrm{p}<0.05$. Multivariate analysis was performed by using logistic regression analysis. This is aims to determine the most important characteristic factors for the prevention of COVID-19 in health care workers.

The ethics committee of Sriwijaya University School of Public Health and Health Research approved this study (code: 153/UN9.FKM/TU.KKE/2021). We explained the purpose of this research at first to the participants before they deliberately participated in it.

\section{Results}

Based on the univariate analysis approach, the results obtained from data analysis are shown in Table 1. Meanwhile, based on bivariate and multivariate analysis the results are shown in Table 2. 
Table 1. Frequency Distribution Based on Health Care Workers' Characteristics, knowledge, attitude, and practice $(\mathrm{N}=\mathbf{2 5 5})$

\begin{tabular}{|c|c|c|}
\hline $\begin{array}{l}\text { Variable } \\
\end{array}$ & Frequency & Percentage $(\%)$ \\
\hline \multicolumn{3}{|l|}{ Managing COVID-19 patients } \\
\hline Yes & 149 & 58.4 \\
\hline No & 106 & 41.6 \\
\hline \multicolumn{3}{|l|}{ Occupation } \\
\hline Doctor & 54 & 21.2 \\
\hline Dentist & 10 & 3.9 \\
\hline Midwife & 39 & 15.3 \\
\hline Nurse & 122 & 47.8 \\
\hline Medical analyst & 30 & 11.8 \\
\hline \multicolumn{3}{|l|}{ Age-group (years) } \\
\hline$\leq 35$ & 215 & 84.3 \\
\hline$>35$ & 40 & 15.7 \\
\hline \multicolumn{3}{|l|}{ Gender } \\
\hline Male & 58 & 22.7 \\
\hline Female & 197 & 77.3 \\
\hline \multicolumn{3}{|l|}{ Education } \\
\hline$\leq$ Bachelors & 228 & 89.4 \\
\hline > Bachelors & 27 & 10.6 \\
\hline \multicolumn{3}{|l|}{ Year of experience } \\
\hline$\leq 5$ & 181 & 71 \\
\hline$>5$ & 74 & 29 \\
\hline \multicolumn{3}{|l|}{ Source of information on COVID-19* } \\
\hline WHO & 196 & 76.6 \\
\hline Indonesian Government Policy & 176 & 69.2 \\
\hline Social media e.g., WhatsApp, Facebook & 186 & 73 \\
\hline News media e.g., TV, radio, newspaper & 159 & 62.4 \\
\hline Journals & 87 & 34.6 \\
\hline Others (Medicine Magazine) & 1 & 0.4 \\
\hline \multicolumn{3}{|l|}{ Knowledge } \\
\hline Poor & 89 & 34.9 \\
\hline Good & 166 & 65.1 \\
\hline \multicolumn{3}{|l|}{ Attitude } \\
\hline Negative & 102 & 40 \\
\hline Positive & 153 & 60 \\
\hline \multicolumn{3}{|l|}{ Practices } \\
\hline Poor & 119 & 46.7 \\
\hline Good & 136 & 53.3 \\
\hline
\end{tabular}

*Multi-select questions

Table 1 shows that the characteristics of health care workers. Most respondents were managing COVID-19 patients (58.4\%). The highest percentage of profession were nurses (47.8\%). Furthermore, the proportion of respondents aged $\leq 35$ years old were $84.3 \%$ and most of them were female (77.3\%). More than half of the respondents (89.4\%) had bachelor's or lower studies. Many of them have equal or less than 5 years of experience (71\%). The main sources of COVID-19 information were WHO (76.6\%). Most of respondents have good knowledge (65.1\%), positive attitude (60\%), and good practice (53.3\%). 
Table 2. Bivariate Analysis of Factors Associated with Practices of Preventing COVID-19 among Health Care Workers

\begin{tabular}{|c|c|c|c|c|c|c|c|}
\hline \multirow{4}{*}{ Variables } & \multicolumn{4}{|c|}{ Practice Toward COVID-19 } & \multirow{4}{*}{ P-Value } & \multirow{4}{*}{ PR } & \multirow{4}{*}{$95 \% \mathrm{CI}$} \\
\hline & & Prev & tion & & & & \\
\hline & \multicolumn{2}{|c|}{ Poor } & \multicolumn{2}{|c|}{ Good } & & & \\
\hline & $\mathbf{n}$ & $\%$ & $\mathbf{n}$ & $\%$ & & & \\
\hline \multicolumn{8}{|l|}{ Age-group (years) } \\
\hline$\leq 35$ & 105 & 48.8 & 110 & 51.2 & 0.107 & 1.395 & $0.895-2.175$ \\
\hline$>35$ & 14 & 35 & 26 & 65 & & & \\
\hline Total & 119 & 46.7 & 136 & 53.3 & & & \\
\hline \multicolumn{8}{|l|}{ Gender } \\
\hline Male & 29 & 50 & 29 & 50 & 0.563 & 1.094 & $0.812-1.476$ \\
\hline Female & 90 & 45.7 & 107 & 54.3 & & & \\
\hline Total & 119 & 46.7 & 136 & 53.3 & & & \\
\hline \multicolumn{8}{|c|}{ Managing COVID-19 patients } \\
\hline Yes & 72 & 48.3 & 77 & 51.7 & 0.530 & 1.090 & $0.832-1.428$ \\
\hline No & 47 & 44.3 & 59 & 55.7 & & & \\
\hline Total & 119 & 46.7 & 136 & 53.3 & & & \\
\hline \multicolumn{8}{|l|}{ Education } \\
\hline$\leq$ Bachelors & 112 & 49.1 & 116 & 50.9 & $0.022 *$ & 1.895 & $0.988-3.634$ \\
\hline$>$ Bachelors & 7 & 25.9 & 20 & 74.1 & & & \\
\hline Total & 119 & 46.7 & 136 & 53.3 & & & \\
\hline \multicolumn{8}{|l|}{ Year of experience } \\
\hline$\leq 5$ & 88 & 48.6 & 93 & 51.4 & 0.328 & 1.161 & $0.854-1.578$ \\
\hline$>5$ & 31 & 41.9 & 43 & 58.1 & & & \\
\hline Total & 119 & 46.7 & 136 & 53.3 & & & \\
\hline \multicolumn{8}{|l|}{ Knowledge } \\
\hline Poor & 38 & 42.7 & 51 & 57.3 & 0.352 & 0.875 & $0.657-1.166$ \\
\hline Good & 81 & 48.8 & 85 & 51.2 & & & \\
\hline Total & 119 & 46.7 & 136 & 53.3 & & & \\
\hline \multicolumn{8}{|l|}{ Attitude } \\
\hline Negative & 72 & 70.6 & 30 & 29.4 & $0.000 *$ & 2.298 & $1.756-3.007$ \\
\hline Positive & 47 & 30.7 & 106 & 69.3 & & & \\
\hline Total & 119 & 61.6 & 136 & 53.3 & & & \\
\hline
\end{tabular}

*Significant if the p-value $<0.05$

According to Table 2, it shows that no significant correlation between characteristics and practice toward COVID-19 prevention, except for education. Respondents with the same level of education as bachelor's degree had $49.1 \%$ higher bad practices, than those with postgraduate education. Meanwhile, $48.8 \%$ of respondents (aged less than or equal to 35 years) had poor COVID-19 prevention practices higher than respondents aged over 35 years. In addition, $50 \%$ of respondents are males who have bad practices. The same results were also found in $45.7 \%$ of women. In total of $48.3 \%$ respondents are treat for COVID-19 patients have bad practices. Furthermore, a total of $48.6 \%$ of respondents who have experience equal to or less than 5 years have higher bad practices than respondents who have experience of more than 5 year

Furthermore, the bivariate analysis shows that $42.7 \%$ of respondents have poor knowledge and poor practices lower than respondents who have good knowledge. The chi-square test showed no significant correlation between knowledge and practice toward COVID-19 prevention. While $70.6 \%$ of respondents have negative attitude and poor practice much higher than respondents who have positive attitude, there is a significant correlation between attitude and practice. 
Table 3. Multivariate Analysis with Multiple Logistic Regression

\begin{tabular}{llllll}
\hline Variable & B & S.E & Sig. & $\operatorname{Exp(B)}$ & $\mathbf{9 5 \%}$ CI for $\operatorname{Exp}(\mathbf{B})$ \\
\hline Attitude & 1.689 & 0.279 & 0.000 & 5.413 & $3.132-9.355$ \\
Constant & -2.564 & 0.469 & 0.000 & 0.077 & \\
\hline
\end{tabular}

Variables that can be used for multivariate analysis are age, education, and attitude. This is because the p-value found is below 0.25 . The final multivariate analysis model shows in Table 3 that there is only one independent variable that affects the dependent variable, namely the attitude variable. The Prevalence Ratio (PR) value shows that health workers who have a negative attitude have 5.413 times bad practices compared to health workers who have a positive attitude. The confidence interval in this case is 3.132-9.355. Researchers believe that negative attitudes are a risk factor for COVID-19 prevention practices in health care workers in $95 \%$ of the general population.

\section{Discussion}

OSHA (Management of Manpower and Occupational Safety) stated that the occupations with the most risk of being exposed to COVID-19 are health workers. ${ }^{8}$ Thus, it is necessary to notice the prevention of COVID-19 as early as possible. ${ }^{13}$ The practices of prevention could be affected by knowledge and attitudes about COVID-19. In-depth knowledge supports optimistic attitudes and correct work practices might help to avoid the risk of infection. ${ }^{17}$ This study showed a correlation between education, attitude, and practice. However, it was found that the most dominant factor affecting to COVID-19 prevention among health care workers was attitude.

The current study shows that most of the participants get the COVID-19 information from WHO. Olum R et.al suggested, that international health organizations WHO could be the source information on COVID-19. ${ }^{14}$ Yet, this study has not analysed the knowledge based on the source of information. More than half of health workers had good knowledge (65.1\%). This study has results that are no significant different from the research in Uganda, which showed that $69 \%$ of respondents were considered to have good knowledge. ${ }^{14}$ According to a study by Haghighi K et al, it was found about $72.8 \%$ of health care workers had sufficient knowledge ${ }^{21}$, while a study by Sidrap shows $77.5 \%$ of health workers had good knowledge. ${ }^{22}$ Furthermore, the study by Maleki S et.al. shows $99 \%$ of respondents had excellent knowledge levels on the disease modes of transmission. ${ }^{23}$ In line with the study conducted by Rizki, ${ }^{24}$ it was stated that most Indonesian health care workers have good knowledge. In contrast, a study by Bhagavathula AS et.al. revealed about $61 \%$ of health care workers had poor knowledge of the virus transmission. ${ }^{20}$

Overall, $60 \%$ of health care workers had a positive attitude in handling the COVID-19. This result is similar to another study conducted in Nepal, it was found that around $53.4 \%$ of health care workers had a positive in handling COVID-19. This is similar because only half of the health workers believe that Nepal can win the fight against COVID-19. Besides the support from family 
members, they are still lack self-confidence as anxiety and anxiety in the workplace increase. ${ }^{17}$ This is in contradict with a study conducted in Vietnam where more than $90 \%$ of people responded positively to COVID-19 and only three-quarters of respondents have no idea if they might be infected with the disease. In addition, they are also think that one of their family members might also be infected and quarantined for suspected infection. ${ }^{19}$ This study found that the attitudes and practices of health workers were significantly lower than those who cared for COVID-19 patients. This may be because $44.3 \%$ of respondents are afraid to treat suspected as COVID-19 patients. It was confirmed by a study in Jordan which showed that anxiety, depression, and stress are increase among health care workers during the COVID-19 pandemic. ${ }^{25}$ Men are more likely to have higher levels of attitudes than women, but Sahar $\mathrm{J}$ found women have significantly higher levels of attitudes. ${ }^{26}$ However, other studies found no significant difference between attitude and gender. ${ }^{14,17,27}$ The experience of 1-5 years shows that the higher attitude occurs because of the longer experience in dealing with emergencies, it will increase the confidence and optimism in health workers. ${ }^{17}$

More than half of the respondents in this study had good practices $(53,3 \%)$. The percentage is lower than the results of study conducted by Olum R et.al. and Limbu et.al. which showed that $74 \%$ and $81,5 \%$ of the respondents had good practices, respectively. ${ }^{14,17}$ It is consistent with an Iranian study where 67.72 wrote best practices. ${ }^{21}$ A study in China showed that $85 \%$ of health care workers are afraid of being infected in the workplace. Health care workers must also deal with various emergencies and are very likely to be infected. ${ }^{28}$

The correlation between education or attitudes towards COVID-19 prevention practices was found to be significant. Specifically, attitude is an essential factor that correlates with COVID-19 prevention practices. The prevalence ratio of the attitude variable is 5.413 and indicates that health care workers that have negative attitudes also have 5.413 times less practices than health care workers with positive attitude. Researchers believe that negative attitudes are the most risk factor for COVID-19 prevention practices in health care workers in $95 \%$ of the general population. In line with another study by Limbu et.al which shows that practices were significantly correlated with attitude. ${ }^{17}$ In contrast to other studies, based on this study, the factors related to the practice of preventing COVID-19 were age 40 years or older with D3 as the last education. ${ }^{14}$ Study by Zhang et.al. shows that work experience and job category were some risk factors that influences health care workers' practice. $^{28}$

There are many factors may cause differences in results between studies, such as time, country, health workforce composition, government policies, and information sources. However, this is the first study that evaluates the COVID-19 prevention on Palembang health workers'. According to the respondents, it is found that $26.3 \%$ of the respondents never participate in the regular COVID-19 training organized by the hospital and $40 \%$ rarely participate. Thus, the health 
system needs to recognize the reason of an intervention plan to increase knowledge alone is not enough. Immediate action should be taken to promote correct practices regarding infectious diseases, especially during the COVID-19 pandemic. On the other hand, the worst-hit areas always have the necessary equipment is also needed to be improved, such as: the provision of PPE, a good working environment, adequate changing rooms, and the role of the government in coordinating efforts to ensure. ${ }^{24,29}$ It is recommended to standardize the data upload to regional and national authorities and creates a common basis for scientific comparisons of the effects of a pandemic on which new strategies should also be improved to prevent the spread of COVID-19. ${ }^{30}$

The limitation of this study is a larger population needed. Therefore, it could be compared between hospitals that neither treat nor treat COVID-19 patients. Several environmental factors that influenced the practice of health care workers were not discussed in this study. The examination in this study was only shows based on respondents' answers and did not observe the practice of health workers directly. This research is also did not focus on health care facilities and policies that might support the practice of health care workers. Thus, further research with larger samples is suggested by using mixed methods and direct observations, on the practices carried out by health workers. Training and periodic evaluations can also be conducted to improve knowledge, attitudes, and practices in COVID-19 prevention. The training that can be carried out is such as socializing the steps for using PPE properly, the right way to use PPE, the transmission of COVID-19 prevention, procedures for handling patients, and COVID-19 suspects.

\section{Conclusion}

The practices by health care workers in Palembang for the prevention of COVID-19 were largely associated with their knowledge, attitude, and some characteristics (age, years of experience, and involvement of dealing with COVID-19). Older health care workers are 3.2 times more likely to apply best practices than younger health care workers. But it is recommended that further training and research on health care workers be conducted. It aims to analyse the availability of PPE, adequate facilities, hospital policies, or other factors that might influence health care workers, and motivate them to practice.

\section{Acknowledgment}

We would like to thank the staff and health workers of Siti Fatimah Hospital, South Sumatra, Gandus Hospital Palembang, and Sriwijaya Hospital Palembang as well as all respondents who have provided assistance and support for this research.

\section{Funding}

The authors should state that they have no funding for the research. 


\section{Conflict of Interest}

The authors declare that they have no conflict of interest.

\section{References}

1. Ather A, Patel B, Ruparel NB, Diogenes A, Hargreaves KM. Coronavirus Disease 19 ( COVID-19 ): Implications for Clinical Dental Care. J Endod. 2020;19:1-12.

2. Israfil, Wiliyanarti PF, Selasa P. Literature Review : Risk of Death in COVID-19 Patients. Unnes J Public Heal. 2020;9(2):141-7.

3. Zhu N, Zhang D, Wang W, Li X, Yang B, Song J, Zhao X, Huang B, Shi W, Lu W, Niu P, Zhan F. A Novel Coronavirus from Patients with Pneumonia in China, 2019. N engl j med. 2020;382:727-33.

4. WHO. WHO Coronavirus Disease (COVID-19) Dashboard. 23 January 2021. 2021.

5. WHO. Transmission of SARS-CoV-2: implications for infection prevention precautions. 2020 .

6. Li Q, Guan X, Wu P, Wang X, Zhou L, Tong Y, Ren R, Leung KSM, Lau EHY, Wong JY, Xing X, Xiang n, Wu Y, Li C, Chen Q, Li D, Liu T, Zhao J, Liu M, Tu W, Chen C, Jin L, Yang R, Wang Q, Zhou S, Wang R, Liu H, Luo Y, Shao G, Li H, Tao Z, Yang Y, Deng Z, Liu B, Ma Z, Zhang Y, Shi G, Lam TTY, Wu JT, Gao GF, Phil D, Cowling BJ, Yang B, Leung GM, Feng Z. Early Transmission Dynamics in Wuhan, China, of Novel Coronavirus-Infected Pneumonia. N Engl J Med. 2020;382(13):1199-207.

7. Sahin AR, Erdogan A, PM A, Dineri Y, AY C. 2019 Novel Coronavirus (COVID-19) Outbreak: A Review of the Current Literature. Eurasian J Med Oncol. 2020;4(1):1-7.

8. OSHA. Worker Exposure Risk to COVID-19. 2020.

9. Bandyopadhyay S, Baticulon RE, Kadhum M, Alser M, Ojuka DK, Badereddin Y, Kamath A, Parepalli SA, Brown G, Iharchane S, Gandino S, Obiago ZM, Scott S, Manirambona E, Machhada A, Aggarwal A, Benazaize L, Ibrahim M, Kim D, Tol I, Taylor EH, Knighton A, Bbaale D, Jasim D, Alghoul H, Reddy H, Abuelgasim H, Saini K, Sigler A, Abuelgasim L, Romero MM, Kumarendran M, Jamie NA, Ali O, Sudarshan R, Dean R, Kissyova R, Kelzang S, Roche S, Ahsan T, Mohamed Y, Dube AM, Gwini GP, Gwokyala Brown R, Papon MRKK, Li Z, Ruzats SS, Charuvila S, Peter N, Khalidy K, Moyo n, Alser O, Solano A, Perez ER, Tariq A, Gaddah M, Kolovos S, Muchemwa FC, Saleh A, Gosman A, Villanueva RP, Jani A, Khundkar R. Infection and mortality of healthcare workers worldwide from COVID-19 : a systematic review. BMJ Glob Heal. 2020;1-11.

10. Erdem H, Lucey DR. Healthcare worker infections and deaths due to COVID-19: A survey from 37 nations and a call for WHO to post national data on their website. Int J Infect Dis. 
2021;102:239-41.

11. Tim Mitigasi Dokter IDI. Pedoman standar perlindungan dokter di era COVID-19. 2020. 1$91 \mathrm{p}$.

12. Halimatu H, Amelia T. Healhtcare workers security: Jaminan, Regulasi, dan Sanksi. Khatulistiwa Law Rev. 2020;1(2):38-9.

13. WHO. Prevention, identification and management of health worker infection in the context of COVID-19. 2020.

14. Olum R, Bongomin F. Coronavirus Disease-2019: Knowledge, Attitude, and Practices of Health Care Workers at Makerere University Teaching Hospitals, Uganda. Front Public Heal. 2020;8(181):1-9.

15. Yupartini L, Rustiawati E, Sulastri T. Stres Kerja dengan Perilaku Caring Petugas Kesehatan dalam Penanganan Pasien pada Masa Pandemi Covid-19. J Keperawatan Silampari. 2021;4(2):683-9.

16. Murdiyanto J, Suryadi H, Nuryati R, Wijaya T. Survei Mitigasi Risiko Covid-19 Pada Tenaga Kesehatan. J Kesehat Kusuma Husada. 2021;12(2):155-63.

17. Limbu DK, Piryani RM, Id AKS. Healthcare workers ' knowledge, attitude and practices during the COVID-19 pandemic response in a tertiary care hospital of Nepal. PLUS ONE. 2020;12:7-13.

18. Shariff FO, Ladyani F, Priliansyah AL. Gambaran Pengetahuan Sikap Dan Perilaku Dokter Ptt Terhadap Pandemi Covid-19 Di Puskesmas Kabupaten Banyuasin Tahun 2020. MAHESA Malahayati Heal Student J. 2021;1(2):113-21.

19. Giao H, Thi N, Han N, Khanh TV, Ngan VK, Tam VV, An LP. Knowledge and attitude toward COVID-19 among healthcare workers at District 2 Hospital, Ho Chi Minh City. Asian Pacific J Trop Med. 2020;13(6):260-5.

20. Bhagavathula AS, Aldhaleei WA, Rahmani J, Ain A, Dhabi A. Knowledge and Perceptions of COVID-19 Among Health Care Workers: Cross-Sectional Study. JMIR Public Heal Surveill. 2020;6(2):1-9.

21. Haghighi FK, Kouhi P, Amini M, Mohammadkarimi V, Hosseini SA, Moosavi M, Boogar SS. Knowledge, Attitude, and Practice Toward COVID-19 Among Healthcare Workers in Shiraz, Iran. Shiraz E-Med J. 2020;21(12):1-8.

22. Fadli F, Ahmad AS, Safruddin S, Sumbara S, Baharuddin R. Anxiety of Health Workers in the Prevention and Management of Covid-19 in Sidrap Regency. Unnes J Public Heal. 2020;9(2):91-7.

23. Maleki S, Najafi F, Farhadi K, Fakhri M, Hosseini F, Naderi M. Knowledge, Attitude and Behavior of Health Care Workers in the Prevention of COVID-19. Res Sq. 2020;1-17.

24. Rizki SA, Kurniawan J, Budimulia P, Sylvanus P, Alexandra A, Sinaga TD, Kurniawan A, 
Lugito NPH. Knowledge, Attitude, and Practice in Indonesian Health Care Workers Regarding COVID-19. Asia-Pacific J Public Heal. 2021;33(5):662-4.

25. Alnazly E, Khraisat OM, Al-Bashaireh AM, Bryant CL. Anxiety, depression, stress, fear and social support during COVID-19 pandemic among Jordanian healthcare workers. PLoS One. 2021;16(3):1-22.

26. Sahar J, Kiik SM, Wiarsih W, Rachmawati U. Coronavirus disease-19: Public health nurses' knowledge, attitude, practices, and perceived barriers in Indonesia. Open Access Maced J Med Sci. 2020;8(T1):422-8.

27. Saqlain M, Munir MM, Rehman SU, Gulzar A, Naz S, Ahmed Z, Tahir AH, Mashhood M. Knowledge , attitude, practice and perceived barriers among healthcare workers regarding COVID-19 : a cross- sectional survey from Pakistan. J Hosp Infect. 2020;105(3):419-23.

28. Zhang M, Zhou M, Tang F, Wang Y, Nie H, Zhang L, You G. Knowledge, attitude, and practice regarding COVID-19 among healthcare worker in Henan, China. J Hosp Infect. 2020;105:19-21.

29. Ranney M, Griffeth V, Jha A. Critical Supply Shortages - The Need for Ventilators and Personal Protective Equipment during the Covid-19 Pandemic. TheNew Engl J Med. 2020;41(1):1969-73.

30. Mendonça-Galaio L, Sacadura-Leite E, Raposo J, França D, Correia A, Lobo R, Soares J, Almeida C, Shapovalova O, Serranheira F, Sousa-Uva A. The COVID-19 impact in hospital healthcare workers: Development of an occupational health risk management program. Port J Public Heal. 2021;38(1):26-31. 